\title{
PERAN PEMBERDAYAAN DAN KETERLIBATAN KERJA TERHADAP KEPUASAN KERJA DAN KINERJA
}

\author{
Marwan $^{1}$, Istib Saroh ${ }^{2}$, Fadhliah M. Alhadar ${ }^{3}$, Jannati T. ${ }^{4}$ \\ ${ }^{1}$ FEB Universitas Khairun; Kota Ternate, 082292199117, ${ }^{2}$ Dinas Pertanian; Kota Ternate, \\ ${ }^{3}$ Fakultas Ekonomi dan Bisnis Universitas Khairun, ${ }^{4}$ STIEM Bongaya Makassar \\ Email : marwan.jamaluddin@yahoo.co.id ${ }^{1}$, istibsaroh.s.hut12@gmail.com ${ }^{2}$, \\ Fadhliahalhadar@yahoo.com ${ }^{3}$,jannatijamaluddin@gmail.com ${ }^{4}$
}

\begin{abstract}
:
The aims of this study was to reveals the roles of empowerment and work involvement on job satisfaction and its impact on the performance of employees in the Ternate Agriculture Agency. The research designs were surveys and questionnaires. The population and sample in this study were the agricultural officials of Ternate City, totaling 135 employees, using the census method. Method of data analysis was Smart PLS 3.0.

the results indicated that 1) empowerment have a positively and significantly effect on job satisfaction, 2) job involvement have positively and significantly effect on job satisfaction, 3) job satisfaction have a positively and significantly effect on employee performance, 4) empowerment have a positively and significantly effect on employee performance, 5) job involvement have a positively and significantly effect on performance, 6) job satisfaction mediated on the effect of empowerment on employee performance and 7) Job satisfaction mediated the effect of work involvement on employee performance. These results indicate that the problem of poor performance in the Ternate Agriculture Agency is closely related to the variables of empowerment, job involvement, and job satisfaction. One of the novelty this research is placement of job satisfaction as a mediation variables.
\end{abstract}

Key Words: Empowerment, Work Involvment, Job Satsfaction, And Performance

\section{Pendahuluan}

Sumber daya manusia dalam struktur pemerintahan disebut Aparatur Sipil Negara (ASN). ASN merupakan abdi masyarakat, yang menjalankaan tugas untuk memberikanpelayanan kepada masyarakat. ASN merupakan salah satu aset utama bagi instansi karena memiliki peran yang sangat penting yaitu sebagai pemikir, perencana dan pengendali aktivitas dalam instansi. Semua instansi membutuhkan pegawai yang mempunyai kinerja yang tinggi, karena merupakan salah satu tolak ukur keberhasilan suatu organisasi dalam mencapai tujuannya. Paradigma penyelengaraan pemerintah telah mengalami pergeseran, dari paradigma rule govermment menjadi good govermance. Dalam rangka untuk mencapai good govermance maka yang dibutuhkan adalah 
pemberdayaan ASN, sehingga ASN memiliki kemampuan yang sesuai dengan bidang tugasnya.

Tujuan dari pemberdayaan ASN adalah untuk memperbaiki efektivitas dan efisiensi kinerja pegawai. Karena dengan diberdayakan aparatur akan mengalami perubahan pengetahuan, keterampilan dan sikapnya terhadap tugas-tugas yang diberikan kepadanya. Hasil penelitian yang dilakukan oleh Ayuningtyas dan Djastuty (2017), Yani et al. (2014) dan Tilaar et al. (2016) serta Suwandana (2016) menyatakan bahwa pemberdayaan memiliki pengaruh yang positif dan signifikan terhadap kepuasan kerja. Pengaruh ini memiliki arti bahwa semakin pegawai diberdayakan organisasi maka tingkat kepuasan kerja pegawai akan meningkat.

Faktor lain yang berpengaruh terhadap kinerja pegawai adalah keterlibatan kerja. Menurut Bahrin (2017) faktor keterlibatan kerja, diindikasikan sebagai faktor dalam peningkatan kinerja. Robbins (2006:94) menyatakan bahwa dalam suatu perusahaan ataupun suatu organisasi, job involvement itu timbul sebagai respon terhadap suatu pekerjaan atau situasi tertentu dalam lingkungan kerja. Hal ini semakin diperjelas dengan hasil-hasil penelitian sebelumnya, misalnya penelitian yang dilakukan oleh Rini dan Hazizma (2013) menyatakan bahwa ada hubungan positif dan signifikan antara keterlibatan kerja dengan kepuasan kerja. Menurut Chungtai (2008), tingkat keterlibatan kerja yang tinggi berperan dalam membentuk kinerja, menambah kualitas dan kuantitas hasil kerja, dan efisiensi kerja yang tinggi. Hasil penelitian yang dikemukakan oleh Sjahruddin et al. (2014) menyatakan bahwa keterlibatan kerja berpengaruh positif dan signifikan terhadap kinerja.

Dalam upaya untuk peningkatan kinerja pegawai di lingkungan Pemerintah Kota ternate, maka setiap tahun pegawai diharuskan menandatangani perjanjian kinerja. Melalui perjanjian kinerja akan terwujud komitmen penerima amanah dan kesepakatan antara penerima dan pemberi amanah atas kinerja terukur tertentu berdasarkan tugas, fungsi, dan wewenang serta sumber daya yang tersedia. Tujuan penyusunan perjanjian kinerja antara lain adalah sebagai wujud nyata komitmen antara penerima dan pemberi amanah untuk meningkatkan integritas, akuntabilitas, transparansi, dan kinerja aparatur.

Walaupun program pemberdayaan dan keterlibatan kerja telah dilakukan, namun permasalahan terkait dengan sumberdaya manusia masih saja terjadi di Dinas Pertanian Kota Ternate. Permasalahan tersebut meliputi tingkat kedisiplinan, dimana hampir tiap hari ada pegawai yang terlambat, meninggalkan tempat kerja lebih awal ataupun mangkir, hal ini terlihat dari data absensi pegawai yang ada. Masalah ketidakhadiran pegawai ini, merupakan masalah yang klasik karena setiap tahun tidak ada perbaikan, akibatnya sangat berpengaruh pada produktivitas kerja pegawai. Selain itu, masalah lain yang ada pada dinas Pertanian Kota Ternate adalah masih adanya pegawai yang bekerja tidak sesuai dengan analisis jabatan mereka, penempatan pegawai yang tidak sesuai dengan keahliannya atau ditempatkan di bidang tertentu sedangkan dia tidak punya keahlian tentang bidang itu, alur pendistribusian tugas tidak jelas, pembagian beban kerja tidak merata, ada beberapa kepala bidang yang hanya memberikan pekerjaan kepada staf tertentu saja dan mengabaikan penjenjangan yang semestinya.

Beberapa penelitian terdahulu yang meneliti pengaruh pemberdayaan dan keterlibatan kerja terhadap kepuasan kerja dan kinerja pegawai diantaranya adalah Ayuningtyas dan Djastuti (2017), yang menyatakan bahwa pemberdayaan karyawan memiliki pengaruh yang positif dan signifikan terhadap kepuasan dan kinerja karyawan. Rasjid dan Maramis (2017) juga menyatakan bahwa pemberdayaan dan kepuasan kerja secara bersama-sama berpengaruh terhadap peningkatan kerja pegawai. Septiadi et al. (2017) menyatakan bahwa keterlibatan kerja berpengaruh positif dan signifikan terhadap kinerja pegawai. Sementara Samiun (2017), menyatakan bahwa pemberdayaan pada dimensi arti pekerjaan berpengaruh negatif dan tidak signifikan terhadap kepuasan kerja karyawan. 


\section{Rumusan Masalah}

Berdasarkan latar belakang, dan research gap di atas, maka peneliti ingin mengetahui lebih jauh mengenai:

1. Apakah Pemberdayaan berpengaruh terhadap kepuasan kerja pegawai pada Dinas Pertanian Kota Ternate.

2. Apakah keterlibatan kerja berpengaruh terhadap kepuasan kerja pegawai pada Dinas Pertanian Kota Ternate.

3. Apakah kepuasan kerja berpengaruh terhadap kinerja pegawai Dinas Pertanian Kota Ternate.

4. Apakah pemberdayaan berpengaruh positif terhadap kinerja pegawai Dinas Pertanian Kota Ternate.

5. Apakah keterlibatan kerja berpengaruh positif terhadap kinerja pegawai Dinas Pertanian Kota Ternate.

6. Apakah kepuasan kerja memediasi pengaruh pemberdayaan terhadap kinerja pegawai Dinas Pertanian Kota Ternate.

7. Apakah kepuasan kerja memediasi pengaruh keterlibatan kerja terhadap kinerja pegawai Dinas Pertanian Kota Ternate.

\section{Tujuan Penelitian}

Adapun tujuan dari penelitian ini adalah :

1. Untuk mengetahui dan menganalisis pengaruh pemberdayaan pada kepuasan kerja pegawai pada Dinas Pertanian Kota Ternate.

2. Untuk mengetahui dan menganalisis pengaruh keterlibatan kerja terhadap kepuasan kerja pegawai pada Dinas Pertanian Kota Ternate.

3. Untuk mengetahui dan menganalisis pengaruh kepuasan kerja terhadap kinerja pegawai Dinas Pertanian Kota Ternate.

4. Untuk mengetahui dan menganalisis pengaruh pemberdayaan terhadap kinerja pegawai Dinas Pertanian Kota Ternate

5. Untuk mengetahui dan menganalisis pengaruh keterlibatan kerja terhadap kinerja pegawai Dinas Pertanian Kota Ternate.

6. Untuk mengetahui dan menganalisis pengaruh kepuasan kerja memediasi pemberdayaan terhadap kinerja pegawai Dinas Pertanian Kota Ternate.

7. Untuk mengetahui dan menganalisis pengaruh kepuasan kerja memediasi keterlibatan kerja terhadap kinerja pegawai Dinas Pertanian Kota Ternate.

\section{Landasan Teori \\ Pengertian \\ Pengertian Kinerja Pegawai}

Kinerja merupakan perwujudan dari kemampuan dalam bentuk karya nyata atau merupakan hasil kerja yang dicapai pegawai dalam mengemban tugas dan pekerjaan yang berasal dari perusahaan (Priansa, 2017:49). Oleh karena itu kinerja adalah merupakan hasil dicapai oleh masing-masing individu, kelompok, maupun organisasi dalam suatu waktu tertentu sesuai dengan karakteristik pekerjaan masing-masing. Capaian ini akan menunjukkan sejauh mana tingkat efektifitas di dalam memanfaatkan sumber daya yang dimilikinya, sehingga dapat menjadi dasar untuk menilai tingkat keunggulannya.

\section{Pengertian Kepuasan Kerja}

Tinggi rendahnya kepuasan kerja dapat memberikan dampak yang tidak sama. Hal ini sangat bergantung pada sikap mental individu yang bersangkutan (Priansa, 2017:228). Byars dan Reu dalam Priansa (2017:228), mengatakan bahwa kepuasan kerja yang tinggi akan mendorong terwujudnya tujuan perusaan secara efektif. Sebaliknya tingkat kepuasan yang rendah merupakan ancaman yang akan membawa kehancuran. Sementara 
itu menurut Handoko (2003:193) kepuasan kerja adalah keadaan emosional yang menyenangka atau tidak menyenangkan dengan mana karyawan memandang pekerjaannya. Atas dasar pengertian tersebut, maka sesungguhanya rasa tingkat kepuasan kepada pekerjaan akan dapat memberikan dampak kepada organisasi masing-masing. Pada umumnya rasa tersebut akan berjalan searah, jika tingkat kepuasan tersebut positif akan dapat mendorong kepada muncul tanggung jawab untuk membantu organisasi ke arah pencapaian tujuan. Sebaliknya jika tingkat kepuasan tersebut rendah, maka akan menyebabkan muncul sikap yang kontra produktif. Seperti hilangnya girah kerja dan rendahnya tingkat kedisiplinan. Yang pada akhirnya akan menyebabkan munurunnya kinerja. Oleh sebab itu sangat penting bagi semua organisasi untuk dapat memenuhi berbagai kebutuhan para pekerjanya.

\section{Pengertian Pemberdayaan}

Menurut Sunarta (2011:38), pemberdayaan berarti memampukan, memberi kesempatan, dan mengijinkan diartikan baik melalui inisiatif sendiri maupun dipicu orang lain. Menurut beberapa literatur ada beberapa hal yang harus dilakukan untuk membentuk lingkungan yang mendukung program pemberdayaan yaitu : 1) membentuk tim kerja komunikasi yang terbuka dengan pekerja; 2)Memberikan pengukuran, umpan balik, dan pengutan; 3) Dukungan manajemen dengan pemberian reinforcement); 4) Memberikan wewenang dan tanggung jawab yang cukup bagi pekerjaan untuk menentukan tindakan yang dibutuhkan untuk menyelesaikan berbagai tugas yang dibebankan. 5) Menciptakan aturan dan system yang lebih fleksibel. Sehingga pada intinya dalam hal pemeberdayaan ini adalah bagaimana kita memahami potensi setiap sumber daya manusia yang kita miliki lalu mengembangkan berbagai program untuk memperkuat potensi setiap orang. Selanjutnya adalah memberikan ruang dan kesempatan yang sama kepada setiap orang untuk dapat memberikan kemampuan terbaiknya.

\section{Pengertian Keterlibatan Kerja (Job Involvement)}

Konsep keterlibatan kerja pertama kali diperkenalkan oleh Lodahl \& Kejner (1965). Sebastianus et al. (2017:3109), menyatakan keterlibatan kerja adalah seberapa besar identifikasi secara psikologis individu terhadap pekerjaannya. Nasution et al. (2018: 126 - 127), menyatakan bahwa keterlibatan kerja, merupakan internalisasi nilai-nilai tentang kebaikan pekerjaan. Sedangkan menurut Kanungo, dalam Nasution et al (2018:127), keterlibatan kerja adalah tingkat sejauh mana karyawan menilai bahwa pekerjaan yang dilakukannya memiliki potensi untuk memuaskan kebutuhannya sebagai hasil dari proses identifikasi psikologis yang dilakukan karyawan terhadap tugas yang bersifat khusus atau pekerjaannya secara umum yang mana proses tersebut bergantung pada sejauh mana kebutuhan baik intrinsic maupun ekstrinsik, dirasa penting.

\section{Kerangka Konseptual dan Hipotesis}

\section{Pengaruh Pemberdayaan Terhadap Kepuasan Kerja}

Bekerja dalam kondisi yang diberdayakan memiliki dampak yang positif bagi karyawan, yaitu meningkatkan perasaan keyakinan diri dan kepuasan kerja, motivasi yang lebih tinggi, dan keletihan fisik/mental yang rendah. Situasi kerja yang diberdayakan secara struktural akan lebih besar kemungkinannya untuk memiliki praktek manajemen yang bisa meningkatkan perasaan pekerja tentang kepercayaan pada organisasi dan kepuasan kerja. Hubungan positif antara pemberdayaan pegawai dengan kepuasan kerja juga dapat didukung dari hasil penelitian yang telah dilakukan oleh Ayuningtyas dan Djastuty (2017:4) dan Yani et al. (2016:4184-4185), Tilaar et al. (2014:998). 


\section{Pengaruh Keterlibatan Kerja Terhadap Kepuasan Kerja}

Wibowo (2016), menyatakan hubungan antara kepuasan kerja dengan variabel keterlibatan kerja dapat bersifat negatif atau positif. Pelibatan kerja menunjukkan kenyataan dimana individu secara pribadi dilibatkan dengan peran kerjanya. Penelitian menunjukkan bahwa pelibatan kerja mempunyai hubungan moderat dengan kepuasan kerja, untuk itu manajer di dorong memperkuat lingkungan kerja yang memuaskan untuk mendorong keterlibatan kerja. Hubungan positif antara keterlibatan kerja dengan kepuasan kerja pegawai telah didukung oleh beberapa hasil penelitian terdahulu, diantaranya oleh Rini dan Hazizma (2013:234) dan Nasution(2018:130)

\section{Pengaruh Kepuasan Kerja Terhadap Kinerja}

Wibowo (2016:420, menggambarkan adanya hubungan timbal balik antara kinerja dan kepuasan kerja. Di satu sisi dikatakan kepuasan kerja menyebabkan peningkatan kerja sehingga pekerja yang puas akan lebih produktif. Kaitan kepuasan kerja dengan kinerja karyawan juga dikemukakan oleh Ostroff (1992:963), ditunjukkan oleh keadaan perusahaan dimana karyawan yang lebih terpuaskan cenderung lebih efektif daripada perusahaan-perusahaan dengan karyawan yang kurang terpuaskan. Dessler dalam Priansa (2017), yang menyatakan bahwa kepuasan kerja antara lain mempunyai peran untuk mencapai produktivitas dan kualitas standar yang lebih baik, menghindari terjadinya kemungkinan membangun kekuatan kerja yang lebih stabil, serta penggunaan sumber daya manusia yang lebih efisien. Beberapa penelitian yang menyatakan bahwa kepuasan kerja berpengaruh positif dan signifikan terhadap kinerja pegawai yaitu Rini dan Hazizma (2013:234) dan Ayuningtyas dan Djastuty (2017:4), Rasjid dan Maramis $(2017 ; 78)$ dan Nasution $(2018: 131)$.

\section{Pengaruh Pemberdayaan Terhadap Kinerja}

Menurut Wibowo (2008:117), pemberdayaan akan meningkatkan kinerja organisasi dan individu dengan meningkatkan bakatnya secara penuh, yaitu dengan cara mendorong dan memberikan kesempatan kepada pegawai untuk mengambil keputusan dan tanggung jawab dalam melaksanakan pekerjaannya guna member kontribusi pada tujuan organisasi. Semakin diberdayakan pegawai maka pegawai akan memberikan kontribusi yang lebih besar pada kinerjanya. Hal ini sesuai dengan hasil dari beberapa penelitian yang menyatakan bahwa permberdayaan berpengaruh positif terhadap kinerja pegawai yaitu antara lain oleh Rasjid dan Maramis (2017:72) dan Anuraga (2017:3316)

\section{Pengaruh Keterlibatan Kerja Terhadap Kinerja}

Robbins (2015:34), menyatakan bahwa pegawai dengan tingkat keterlibatan tinggi sangat memihak dan benar-benar peduli dengan bidang pekerjaan yang mereka lakukan. Tingkat keterlibatan kerja yang tinggi berhubungan dengan kinerja. Sedangkan menurut Priansa (2017), tingkat keterlibatan kerja yang tinggi akan menurunkan tingkat ketidakhadiran pegawai, dengan sendirinya pegawai yang tingkat ketidakhadirannya rendah dapat meningkatkan kinerjanya. Menurut Chungtai (2008), tingkat keterlibatan kerja yang tinggi berperan dalam membentuk kinerja, menambah kualitas dan kuantitas hasil kerja, dan efisiensi kerja yang tinggi. penelitan lainnya yang menyatakan bahwa keterlibatan kerja pegawai berpengaruh positif terhadap kinerja pegawai, yaitu Rasjid dan Maramis (2017:72).

\section{Kepuasan Kerja Memediasi Pengaruh Pemberdayaan Terhadap Kinerja Pegawai}

Suatu organisasi yang memiliki pemberdayaan yang baik, apabila pemberdayaan yang diterapkan pada organisasinya adalah mendayagunakan segala potensi yang dimiliki sebagai kekayaan organisasi secara optimal. Adapun penelitian yang dilakukan Rini dan Hazizma (2013;243), mengungkapkan adanya hubungan linier antara pemberdayaan dengan kinerja dan kepuasan kerja, Rahayu dan Sudibya (2014:829-830). 


\section{Kepuasan Kerja Memediasi Pengaruh Keterlibatan Kerja Terhadap Kinerja Pegawai.}

Penelitian yang mengungkapan bahwa kepuasan kerja memediasi pengaruh keterlibatan kerja terhadap kinerja adalah Nasution et al (2018:131), mengungkapkan bahwa keterlibatan secara tidak langsung mempunyai pengaruh terhadap kinerja pegawai melalui kepuasan kerja. Sedangkan Rini dan Hazizma (2013:243), mengungkapkan bahwa ada hubungan linier antara keterlibatan kerja dan kinerja pegawai dengan kepuasan kerja dilakukan.

Berdasarkan pada kerangka konsep yangdiperoleh dari berbagai teori maupun hasil-hasil riset terbaru yang relevan, maka dapat dibangun sebuah model penelitian sebagai berikut:

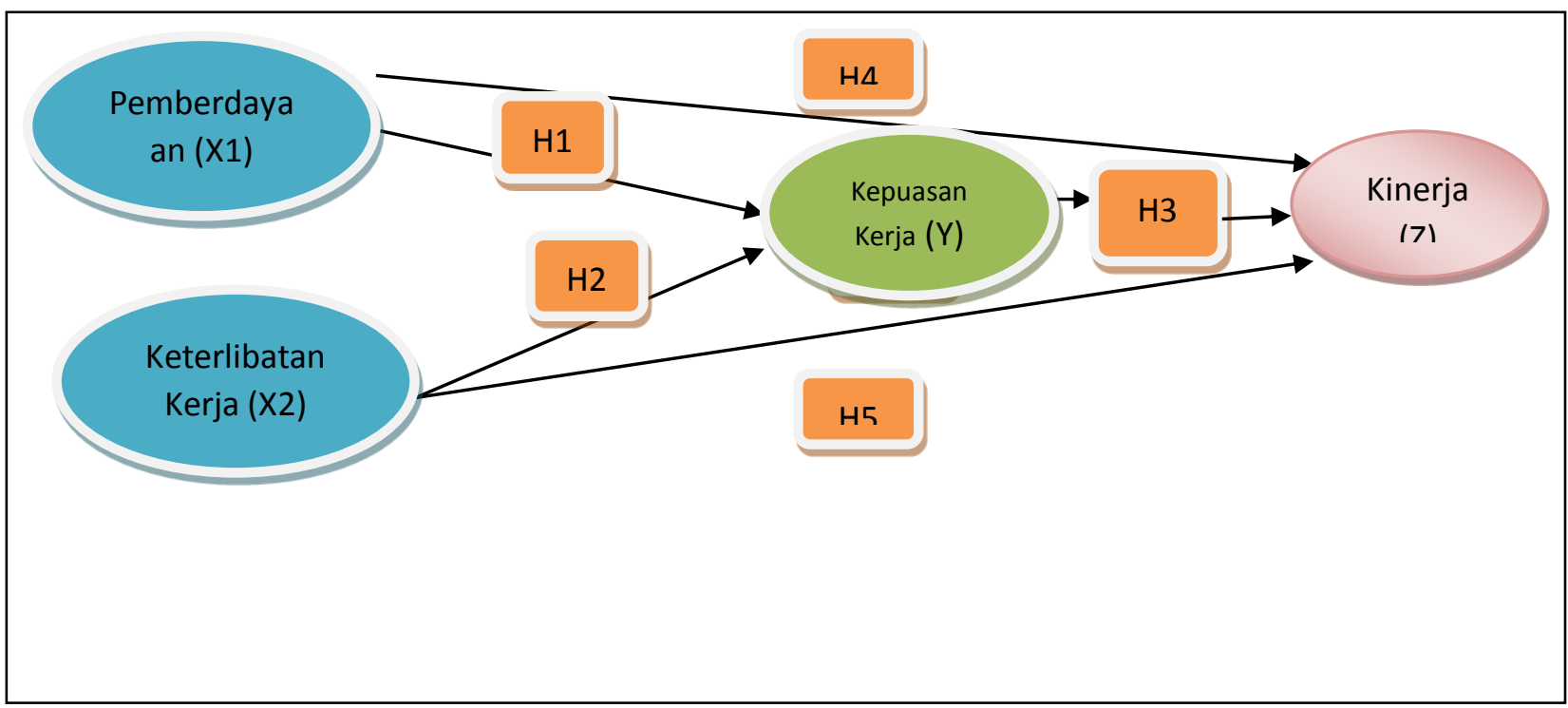

Gambar 2.1 : Kerangka Penelitian

\section{Hipotesis Penelitian}

Hipotesis 1: Pemberdayaan berpengaruh secara positif dan signifikan terhadap kepuasan kerja pegawai pada Dinas Pertanian Kota Ternate.

Hipotesis 2 : Keterlibatan kerja berpengaruh secara positif dan signifikan terhadap kepuasan kerja pegawai pada Dinas Pertanian Kota Ternate.

Hipotesis 3 : Kepuasan kerja berpengaruh secara positif dan signifikan terhadap kinerja pegawai Dinas Pertanian Kota Ternate.

Hipotesis 4: Pemberdayaan berpengaruh secara positif dan signifikan terhadap kinerja pegawai Dinas Pertanian Kota Ternate.

Hipotesis 5 : Keterlibatan kerja berpengaruh positif terhadap kinerja pegawai Dinas Pertanian Kota Ternate.

Hipotesis 6: Kepuasan kerja memediasi pengaruh pemberdayaan terhadap kinerja pegawai Dinas Pertanian Kota Ternate.

Hipotesis 7 : Kepuasan kerja memediasi pengaruh keterlibatan kerja terhadap kinerja pegawai Dinas Pertanian Kota Ternate. 


\section{Metode Penelitian}

\section{Populasi Dan Sampel}

Populasi penelitian adalah seluruh pegawai pada Dinas Pertanian Kota Ternate yang berjumlah 138 orang pegawai, baik yang berstatus sebagai Pegawai Negeri Sipil (PNS), Pegawai Tidak Tetap (PTT) maupun Tenaga Harian Lepas (THL).

\section{Jenis Dan Sumber Data}

Data dalam penelitian ini terdiri dari data primer dan sekunder. Data primer merupakan data penelitian yang diperoleh secara langsung dari sumbernya berupa wawancara atau kuisioner. Data primer pada penelitian ini berupa biografi para responden dan persepsi mereka terkai dengan variable penelitian.

Data sekunder diperoleh secara tidak langsung yang berhubungan dengan penelitian, seperti data mengenai gambaran umum lokasi penelitian dan visi misi organisasi dan data pendukung lainnya.

\section{Validitas Konstruk}

Validitas kosntruk menunjukan seberapa baik hasil yang diperoleh dari penggunaan suatu pengukuran sesuai teori-teori yang digunakan untuk mendefiisikan suatu kostruk. Validitas konstruk terdiri atas validitas konvergen dan validitas diskriminan Hartono dalam Jogiyanto (2011:70)

\section{Uji Reliabilitas}

Selain uji validitas, PLS juga melakukan uji reliabilitas untuk mengukur konsistensi internal alat ukur. Hartono, dalam Jogiyanto ( 2011:72), Uji Reliabilitas dapat menggunakan dua metode yaitu: Cronbach's alpha dan Composite reliability.

\section{Motode Analisis Data}

\section{Analisis Statistik Inferensial}

Pertial Least Square menggunakan metode principle component analiysis dalam model pengukuran, yaitu blok ekstrasi varian untuk melihat hubungan indikator dengan konstruk latennya dengan menghitung total varian yang terdiri atas varian umum, varian spesifik, dan varian eror, sehingga total varian menjadi tinggi.

\section{Model Persamaan Struktur}

Model analisis struktural tahap pertama yang dibangun dalam penelitian ini dapat dilihat pada gambar berikut ini : 


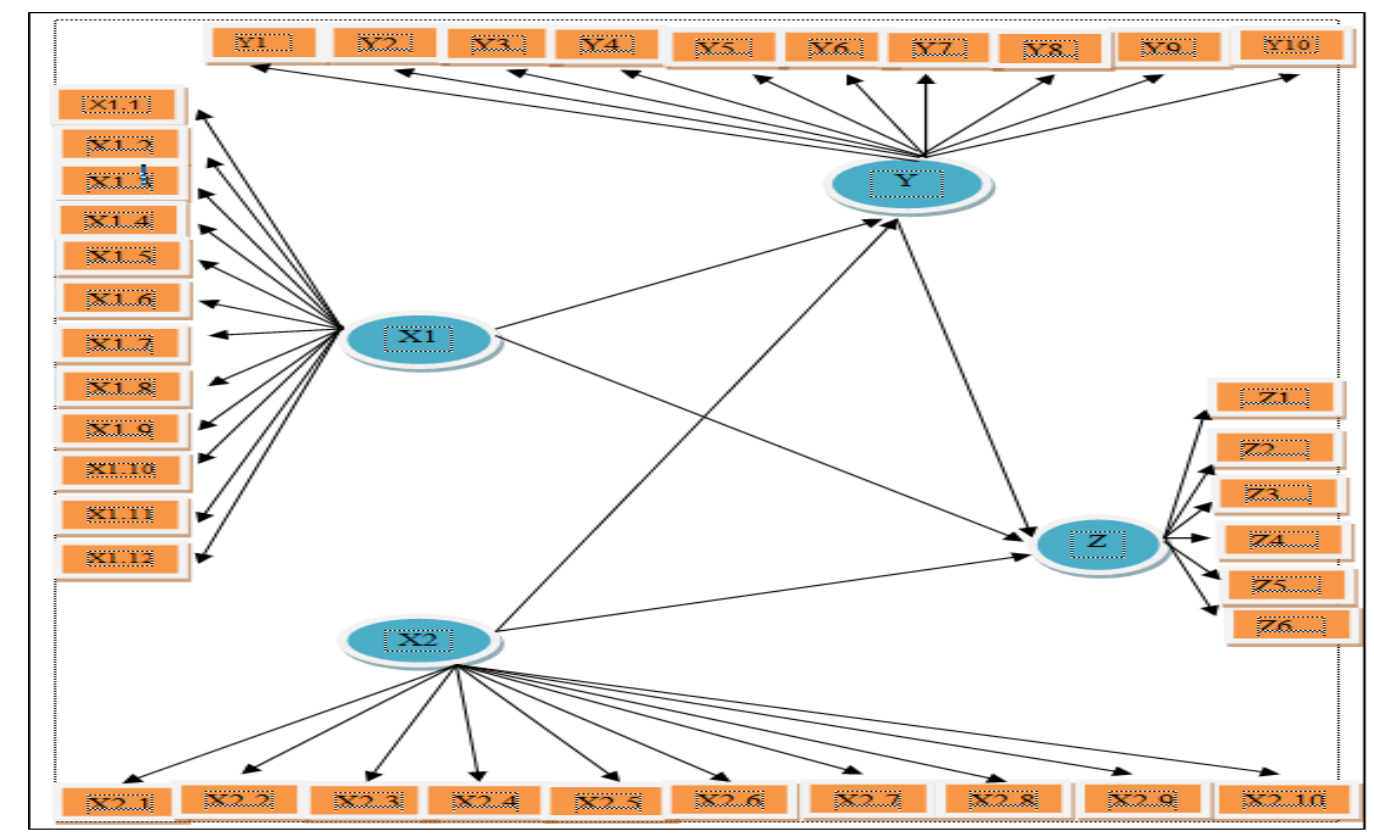

Gambar 3.1 : Model Analisis Struktur

\section{Hasil Penelitian dan Pembahasan}

\section{Pengujian Hipotesa (Resampling Bootstraping)}

Menggunakan SmartPLS 3.0 dan dengan penghitungan bootstrapping untuk uji hipotesis. Bootstrappig digunakan untuk menguji hipotesis sampel maka didapatkan nilainilainya seperti pada gambar 4.1 dan table 4.1. berikut :

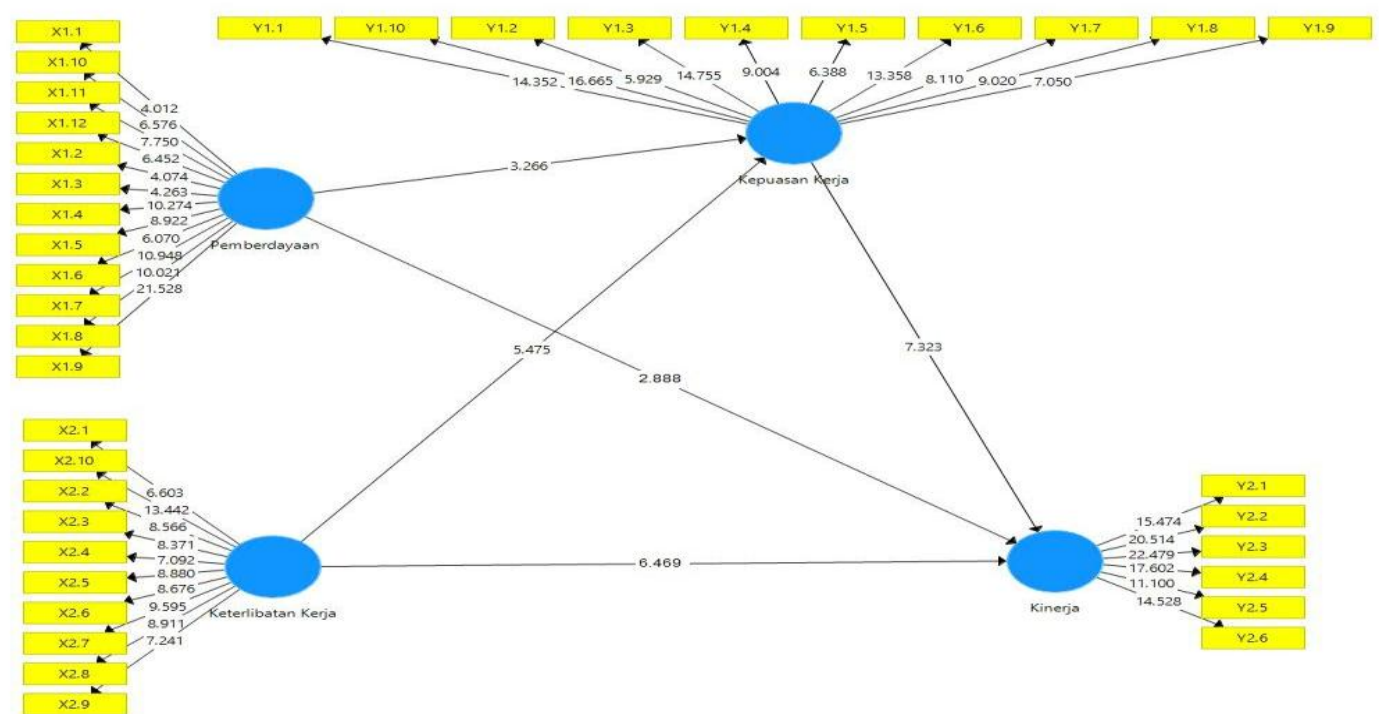

Gambar 4.1. Output Bootstrapping

Tabel 4.1. Pengaruh Langsung (Sumber: Data diolah, 2019.) 


\begin{tabular}{|l|r|r|r|r|r|}
\hline & $\begin{array}{r}\text { Original } \\
\text { Sampel/O }\end{array}$ & $\begin{array}{c}\text { Rata- } \\
\text { rata } \\
\text { Sampel }\end{array}$ & \multicolumn{1}{c|}{$\begin{array}{c}\text { Standar } \\
\text { Deviasi }\end{array}$} & t Statistik & P Values \\
\hline Pemberdayaan -> Kep. Kerja & 0.293 & 0.300 & 0.090 & 3.266 & 0.001 \\
\hline $\begin{array}{l}\text { Keterlibatan Kerja -> Kep. } \\
\text { Kerja }\end{array}$ & 0.420 & 0.430 & 0.077 & 5.475 & 0.000 \\
\hline Kepuasan Kerja -> Kinerja & 0.531 & 0.533 & 0.072 & 7.323 & 0.000 \\
\hline Pemberdayaan -> Kinerja & 0.278 & 0.271 & 0.096 & 2.888 & 0.004 \\
\hline Keterlibatan Kerja -> Kinerja & 0.518 & 0.536 & 0.080 & 6.469 & 0.000 \\
\hline
\end{tabular}

Pembahasan tentang hipotesa ke-6 dan ke-7 yaitu mengenai pengaruh variabel kepuasan kerja sebagai mediasi pada penelitian ini akan dijelaskan secara rinci sesuai dengan hasil perhitungan pada tabel 4.2 dan table 4.3 berikut ini :

Tabel 4.2. Pengaruh Tidak Langsung (Sumber: Data diolah, 2019.)

\begin{tabular}{|c|c|c|c|c|c|}
\hline & $\begin{array}{l}\text { Sampel } \\
\text { Asli }\end{array}$ & $\begin{array}{l}\text { Rata-rata } \\
\text { Sampel }\end{array}$ & $\begin{array}{l}\text { Standar } \\
\text { Deviasi }\end{array}$ & $\begin{array}{l}\mathbf{t} \\
\text { Statistik }\end{array}$ & P Values \\
\hline $\begin{array}{l}\text { Keterlibatan Kerja -> } \\
\text { Kepuasan Kerja -> } \\
\text { Kinerja }\end{array}$ & 0.223 & 0.228 & 0.046 & 4.874 & 0.000 \\
\hline $\begin{array}{l}\text { Pemberdayaan -> } \\
\text { Kepuasan Kerja -> } \\
\text { Kinerja }\end{array}$ & 0.155 & 0.162 & 0.058 & 2.674 & 0.008 \\
\hline
\end{tabular}

Tabel 4.3. Pengaruh total (Sumber: Data diolah, 2019)

\begin{tabular}{|lccc|}
\hline & $\begin{array}{c}\text { Pengaruh } \\
\text { Langsung }\end{array}$ & $\begin{array}{c}\text { Pengaruh Tidak } \\
\text { Langsung }\end{array}$ & $\begin{array}{c}\text { Pengaruh } \\
\text { Total }\end{array}$ \\
\hline $\begin{array}{l}\text { Pemberdayaan -> Kep. } \\
\text { Kerja }\end{array}$ & 0.293 & - & 0.293 \\
\hline $\begin{array}{l}\text { Keterlibatan Kerja -> Kep. } \\
\text { Kerja }\end{array}$ & 0.420 & - & 0.420 \\
\hline Kepuasan Kerja -> Kinerja & 0.531 & - & 0.531 \\
\hline Pemberdayaan -> Kinerja & 0.278 & 0.155 & 0.433 \\
\hline $\begin{array}{l}\text { Keterlibatan Kerja -> } \\
\text { Kinerja }\end{array}$ & 0.518 & 0,223 & 0.741 \\
\hline
\end{tabular}

\section{Pembahasan Hasil Penelitian}

\section{Pengaruh Pemberdayaan Terhadap Kepuasan Kerja}

Berdasarkan hasil analisis data menunjukkan bahwa nilai t statistiknya 3,266 $\geq$ 1,657 (t tabel), dan nilai $P$ Values nya $0,001 \leq 0,05$, sehingga disimpulkan terdapat pengaruh yang signifikan positif antara pemberdayaan terhadap kepuasan kerja pegawai pada Dinas Pertanian Kota Ternate. Hal ini juga dapat diartikan bahwa pemberdayaan berpengaruh signifikan positif terhadap kepuasan kerja, semakin besar pemberdayaan yang diterapkan dalam organisasi terhadap pegawainya akan mengakibatkan peningkatan kepuasan kerja pegawai. 
Hasil penelitian ini sejalan dengan Wibowo (2016:353) bahwa pemberdayaan meningkatkan percaya diri dalam melakukan sesuatu, akibatnya akan terkadi peningkatan kepuasan kerja; kerjasama yang lebih dekat dengan orang lain; bekerja dengan tujuan yang lebih jelas dan mendapatkan prestasi apabila tujuan tercapai. Hasil ini juga sependapat dengan Yani et al. (2016:4198), Tilaar et al. (2014:998). Menurut Ayuningtyas et al. (2017:9), menyatakan bahwa Pemberdayaan dan kepuasan kerja merupakan aspek penting bagi lingkungan kerja yang sehat.

\section{Pengaruh Keterlibatan Kerja Terhadap Kepuasan Kerja}

Berdasarkan hasil analisis data menunjukkan bahwa nilai t statistiknya $5,475 \geq$ 1,657 (t tabel), dan nilai $P$ Values nya $0,000 \leq 0,05$, sehingga terdapat pengaruh yang signifikan positif antara ketelibatan kerja terhadap kepuasan kerja pegawai. Hal ini juga dapat diartikan bahwa keterlbatan kerja berpengaruh signifikan positif terhadap kepuasan kerja, semakin besar keterlibatan pegawai dalam pekerjaanya akan mengakibatkan peningkatan kepuasan kerja pegawai, demikian juga sebaliknya.

Menurut Robbin (2003:91), keterlibatan merupakan tingkat dimana individu secara psikologis memihak pekerjaan mereka, berpartisipasi aktif di dalamnya dan menganggap peting tingkat kerja yang dicapai sebagai bentuk penghargaan diri. Pegawai yang mempunyai keterlibatan tinggi sangat memihak dan benar benar peduli dengan bidang pekerjaan yang mereka lakukan. Kanungo (2013), yang menyatakan bahwa keterlibatan kerja, merupakan internalisasi nilai-nilai tentang kebaikan pekerjaan atau pentingnya pekerjaan bagi keberhargaan seseorang, dimana semakin sering terjadi keterlibatan kerja, akan meningkatkan kepuasan kerja pegawai. Penelitian lainnya adalah oleh Rini et al. (2013:242), Alfian et al. (2017:90) dan Nasution et al. (2018:131).

\section{Pengaruh Kepuasan Kerja Terhadap Kinerja Pegawai}

Berdasarkan hasil analisis data menunjukkan bahwa nilai t statistiknya 7,323 $\geq$ 1,657 (t tabel), dan nilai $P$ Values nya $0,000 \leq 0,05$, sehingga disimpulkan terdapat pengaruh yang signifikan positif antara kepuasan kerja terhadap kinerja pegawai. Hal ini juga dapat diartikan bahwa kepuasan kerja berpengaruh signifikan positif terhadap kinerja pegawai, semakin besar kepuasan kerja pegawai dalam organisasi akan akan mengakibatkan peningkatan kinerja pegawai, demikian juga sebaliknya.

Hasil penelitian ini sesuai dengan pendapat Jacobs dan Solomon dalam Priansa, (2017:232), bahwa korelasi antara kepuasan kerja dan kinerja akan lebih tinggi pada pekerja yang menghargai kinerja yang bagus dibandingkan dengan pekerja yang tidak memberikan penghargaan. Priansa (2016:280) juga menyatakan bahwa pegawai yang memiliki tingkat kepuasan yang tinggi cenderung akan menghasilkan kinerja yang tinggi dalam mengemban pekerjaannya. Hasil penelitian sejalan dengan Alfian et al. (2017:92), Rini dan Hazizma (2013:243), Ayuningtyas dan Djastuty (2017:9), Rasjid dan Maramis (2017:78), Nasution et al. (2018:131) yang menyatakan bahwa pengaruh kepuasan kerja terhadap kinerja adalah positif dan signifikan.

\section{Pengaruh Pemberdayaan Terhadap Kinerja Pegawai}

Berdasarkan hasil analisis data menunjukkan nilai t statistiknya 2,888 $\geq 1,657$ (t tabel), dan nilai $P$ Values nya $0,004 \leq 0,05$, sehingga disimpulkan terdapat pengaruh yang signifikan positif antara pemberdayaan terhadap kinerja pegawai pada Dinas Pertanian Kota Ternate. Hal ini juga dapat diartikan bahwa pemberdayaan berpengaruh signifikan positif terhadap kinerja pegawai, semakin besar pemberdayaan yang diterapkan dalam organisasi yaitu Dinas Petanian Kota Ternate terhadap pegawainya akan mengakibatkan peningkatan kinerja Pegawai.

Hasil penelitian ini sependapat dengan Wibowo (2016:351) yang menyatakan bahwa pemberdayaan dapat mendorong orang untuk lebih terlibat dalam pembuatan keputusan dalam organisasi. Penelitian lainnya yang sama adalah yang telah dilakukan 
oleh Anuraga et al. (2017:3316, Rasjid dan Maramis (2017:76-77). Oleh sebab itu semakin diberdayakan pegawai maka pegawai akan memberikan kontribusi yang lebih besar pada kinerjanya.

\section{Pengaruh keterlibatan kerja terhadap kinerja pegawai}

Berdasarkan hasil analisis data menunjukkan bahwa nilai t statistiknya $6,469 \geq$ 1,657 (t tabel), dan nilai $P$ Values nya $0,000 \leq 0,05$, sehingga terdapat pengaruh yang signifikan positif antara ketelibatan kerja terhadap kepuasan kerja pegawai. Hal ini juga dapat diartikan bahwa keterlbatan kerja berpengaruh signifikan positif terhadap kepuasan kerja, semakin besar keterlibatan pegawai dalam pekerjaanya akan mengakibatkan peningkatan kepuasan kerja pegawai, demikian juga sebaliknya.

Hasil penelitian ini sesuai dengan penelitian yang menyatakan bahwa seseorang yang terlibat dengan pekerjaan akan menganggap pekerjaan memiliki peran penting dalam hidupnya, merasa bahwa kebutuhan kemandirian dan control terhadap pekerjaan terpenuhi serta merasa harga dirinya meningkat seiring dengan peningkatan kinerja. Diantara penelitian tersebut adalah, yang menyatakan bahwa keterlibatan kerja pegawai berpengaruh positif terhadap kinerja pegawai, antara lain oleh Septiadi et al. (2017:3124).

\section{Pengaruh pemberdayaan terhadap kinerja pegawai melalui kepuasan kerja}

Berdasarkan hasil analisis data menunjukkan bahwa nilai t statistiknya $2,674 \geq$ 1,657 (t tabel), dan nilai $P$ Values nya $0,008 \leq 0,05$, sehingga disimpulkan terdapat pengaruh yang signifikan positif pengaruh pemberdayaan terhadap kinerja pegawai melalui kepuasan kerja. Pengaruh langsung antara pemberdayaan ke kinerja adalah signifikan dengan koefisien korelasi sebesar 0,278, pengaruh tidak langsung juga signifikan dengan nilai sebesar 0,155 dan pengaruh total sebesar 0,433 . Berdasarkan hasil analisa data ini maka dapat disimpulkan bahwa variabel kepuasan kerja terbukti sebagai varibel intervening/mediasi. Tipe mediasi yang terjadi pada penelitian ini adalah mediasi parsial. Hasil penelitian ini didukung oleh penelitian sebelumya yang, yang menyatakan pemberdayaan memberikan pengaruh positif dan signifikan terhadap kinerja pegawai melalui kepuasan kerja, Rahayu dan sudibya (2014:829-830).

\section{Pengaruh keterlibatan kerja terhadap kinerja pegawai melalui kepuasan kerja}

Berdasarkan hasil analisis data nilai t statistiknya 4,874 $\geq 1,657$ ( $\mathrm{t}$ tabel), dan nilai $P$ Values nya $0,000 \leq 0,05$. Pengaruh langsung antara keterlibatan kerja ke kinerja adalah signifikan dengan koefisien korelasi sebesar 0,518, pengaruh tidak langsung juga signifikan dengan nilai sebesar 0,233 dan pengaruh total sebesar 0,741 . Berdasarkan hasil analisa data ini maka dapat disimpulkan bahwa variabel kepuasan kerja terbukti sebagai varibel intervening/mediasi. Tipe mediasi yang terjadi pada penelitian ini adalah mediasi parsial. Sehingga disimpulkan terdapat pengaruh yang signifikan positif pengaruh ketelibatan kerja terhadap kinerja pegawai melalui kepuasan kerja pegawai.

Hasil yang sama pada beberapa hasil penelitian terdahulu bahwa kepuasan kerja memediasi pengaruh keterlibatan kerja terhadap kinerja pegawai yaitu oleh Alfian et al. (2017:92), Nasution et al (2018), mengungkapkan bahwa keterlibatan secara tidak langsung mempunyai pengaruh terhadap kinerja pegawai melalui kepuasan kerja. Sedangkan Rini dan Hazizma (2013:325), mengungkapkan bahwa ada hubungan linier antara keterlibatan kerja dan kinerja pegawai dengan kepuasan kerja dilakukan.

\section{Simpulan dan Saran Simpulan}

Berdasarkan hasil penelitian dan pembahasan, maka dapat kesimpulan sebagai berikut: pertama, pemberdayaan dan keterlibatan kerja berpengaruh secara positif dan signifikan terhadap kepuasan kerja pegawai Dinas Pertanian Kota Ternate. Artinya bahwa 
jika variable pemberdayaan dan keterlibatan kerja tinggi maka akan menyebabkan kepuasan kerja akan meningkat, demikian pula sebaliknya. Kedua, kepuasan kerja, pemberdayaan, dan keterlibatan kerja berpengaruh secara positif dan signifikan terhadap kinerja pegawai Dinas Pertanian Kota Ternate. Artinya bahwa jika variable kepuasan kerja, pemberdayaan, dan keterlibatan kerja tinggi maka kinerja para pegawai akan tinggi, demikian juga sebaliknya. Ketiga, kepuasan kerja memediasi pengaruh variabel pemberdayaan dan pengaruh variable keterlibatan kerja terhadap kinerja pegawai Dinas Pertanian Kota Ternate.

\section{Saran}

Berdasarkan pada kesimpulan penelitian, maka dapat diajukan saran sebagai berikut: pertama, pimpinan di seluruh level organisasi perlu untuk melakukan peningkatan pemberdayaan pegawainya secara terus menerus guna memberikan peningkatan terhadap kepuasan kerja pegawai Dinas Pertanian Kota Ternate. Kedua, keterlibatan kerja yang perlu ditingkatkan dalam berbagai aktivitas kerja agar mereka mau dan senang bekerja sama, baik dengan pimpinan ataupun dengan sesama teman kerja. Salah satu caranya memberikan kesempatan kepada pegawai dalam pembuatan keputusan terkait bidang pekerjaannya. Ketiga, peneliti lain yang ingin mengembangkan penelitian ini, dapat menambahkan variabel-variabel lain di luar dari variable penelitian ini.

\section{Daftar Pustaka}

Abdallah, Ayman Bahjat, et al. 2016. An Integrated Model of Job Involvement, Job Satisfaction and Organizational Commitment: A Structural Analysis in Jordan's Banking Sector. Scientific Research Publishing. 28 - 53.

Abdullah, Ma'ruf. 2016. Manajemen dan Evaluasi Kinerja Karyawan. Edisi ke II. Yogyakarta, Aswajah Presindo.

Alfian, Ferri. 2017. Pengaruh Keterlibatan Kerja, Beban Kerja Dan Konflik Peran Terhadap Kepuasan Kerja Serta Dampaknya Terhadap Kinerja Pegawai Pada Dinas Pendidikan Aceh. Jurnal Manajemen Inovasi. Vol. 8. No. 2: 84 - 96.

Anuraga, I Putu Magna; Sintaasih, Desak Ketut; Riana, I Gede. 2017. Pengaruh Kepemimpinan Dan Pemberdayaan Terhadap Motivasi Dan Kinerja Pegawai. E-jurnal Ekonomi dan Bisnis Universitas Udayana 6.9: 3291-3324

Ayuningtyas, Aditya Hapsari dan Djastuti, Indi . 2017. Analisis Pengaruh Pemberdayaan Dan Pengembangan Karir Terhadap Kinerja Karyawan Dengan Kepuasan Kerja Sebagai Variabel Intervening. Diponegoro Journal of Management. Vol. 6 No. 3: $9-13$.

Azzahra, Fariha dan Maryati, Tri. 2016. Dampak Job Involvement Dalam Meningkatkan Kinerja Pegawai Melalui Komitmen Organisasi. Jurnal Bisnis Teori dan Implementasi. Vol. No. 2: $301-324$.

Bangun, Wilson. 2012. Manajemen Sumber Daya manusia. Jakarta. Penerbit Erlangga.

Baron, R. M and Kenny, D. A. 1986. The Moderator-Mediator Variabel Distinction in Social Psychogical Researc. Conceptual, Strategic and Statistical Consideration. Journal of Personality and Social Psychology, 51(6), 11731182. 
Damayanti, Nefi dan Tjendana, Martinus. 2012. Hubungan Motivasi Dan Keterlibatan Kerja Dengan Kinerja. Alitika. Vol. 4 No. 1:31-37.

Dessler, Gary.1999. Manajemen Sumber Daya Manusia’ PT Prenhalindo, Jakarta.

Ferdinand, Augusty T.. 2011. Metode Penelitian Manajemen. Semarang. Badan Penerbit Universitas Diponegoro.

Ghozali, Imam. 2008. Struktural Equqtion Modeling, Metode Alternatif dengan Partial Least Squqre (PLS). Badan Penerbit Universitas Diponegoro, Semarang.

Handoko, T. Hani. 1995. Manajemeen SDM dan Manajemen Personalia. BPFE, Yogyakarta.

Handoko, T. Hani. 2001. Manajemen Persoalia daan Sumber Daya Manusia. Yogyakarta. Haji Masagung.

Hasibuan, Melayu,SP. 2017.Manajemen Sumber Daya Manusia,Edisi Revisi, Cetakan ke 21. PT. Bumi Aksara, Jakarta.Hermawan, Francisea dan Chandra, Eric. 2014. Analisis Pengaruh Pembardayaan Karyawan Terhadap Kepuasan Kerja Di Pt. Sdv Logistic. Jurnal Optimum. Vol. 4 No. 1: $13-21$.

Jogiyanto. (2011). Konsep dan Aplikasi Structural Equational Modeling Berbasis Varian Dalam Penelitian Bisnis: UPP STIM YKPN.

Kanungo, R.N. (1982). Measurement of job and work involvement. Journal of Applied Psychology, 76,341-349.

Kock, Ned. 2017. Which is the best way to measure job performance : Self-perception or official supervisor evaluation?. International Journal of e-Collaboration, 13(2), $1-9$.

Lodahl, T.M. and Kejner, M.M. 1965. The Definition and Measurement of Job Involvement. Journal of Applied Psychology, 49, 24-33.

Macdoal, Scott and MacIntyre, Peter. 1997. The Generic Job Satisfaction Scale: Scale Development and Its Correlates. Employee Assistence Quarterly, 13(2).

MacKinnon, D.P., Fairchild, A.J., dan Fritz, M.S., 2007, Mediation analysis. Annual Review of Psychology, 58, 593-614.

Mangkunegara, A.A. Anwar Prabu . 2001. Manajemen Sumber Daya Perusahaan. Bandung. Remaja Rosdakarya Offset.

Mangkunegara, A.A. Anwar Prabu . 2006. Evaluasi Kinerja Sumber Daya Manusia. Jakarta: Refika Aditama.

Mathias, Robert L. dan Jackson, John H.. 2010. Manajemen Sumber Daya Manusia. Jakarta: Salemba Empat.

Mulyadi. 2004. Akuntansi Manajemen : Konsep, Manfaat, dan Rekayasa. Edisi Ketiga. Cetakan Ketiga. Jakarta : Salemba Empat. 
Nasution, Erni Hayati. 2018. Faktor-Faktor Yang Mempengaruhi Kepuasan Kerja Dan Dampaknya Terhadap Kinerja Pegawai Kanwil Direktorat Jenderal Kekayaan Negara Aceh. Jurnal Magister Manajemen. Vol. 2 No. 1: 123 - 134.

Ostroff, Cheri . 1992. The Relationship between Satisfaction, Attitudes and Performance An Organizational Level Analysis", Journal of Applied Psychology, Vol.77 No.6: 963-974

Priansa, Donny Juni. 2016. Perencanaan dan Pengembangan SDM. Bandung, Penerbit Alfabeta Bandung.

Priansa, Donny Juni. 2017. Manajemen Kinerja Kepegawaian, CV. Pusata Setia, Bandung.

Rahayu, Putu Desyana dan Sudibia, Gede Adnyana. 2014. Peran Kepuasan Kerja dalam Memediasi Pemberdayaan terhadap Kinerja Karyawan pada Hotel Bali Summer. E-Jurnal Manajemen. Vol. 3 Nomor: 2302-8912.

Rasjid, Efendy dan Maramis, Diana R.S.. 2017. Pengaruh Pemberdayaan Dan Kepuasan Kerja Dalam Meningkatkan Kinerja Pegawai Di Lingkungan Politeknik Manado. Prosiding Setrinov ISSN: 2477 - 2097: 72 - 83.

Rini dan Hazizma, L. Suhairi. 2013. Pengaruh Pemberdayaan Karyawan,Kemahiran Diri Dan Keterlibatan Karyawan Terhadap Kepuasan Kerja Dan Kinerja Karyawan.Jurnal Manajemen Bisnis Sriwijaya. Vol. 11 No. 3: 233 - 244.

Rivai, Veithzal dan Sagala, Eva J.. 2015. Manajemen Sumber Daya Manusia Untuk Perusahaan : Dari Teori Ke Praktik. Jakarta. Raja Grafindo Persada.

Robbins, Stephen P. dan Judge, Timothy A.. 2015. Perilaku Organisasi (Organizational Behavior). Jakarta. Salemba Empat.

Robbins, Sthephen P.. 2006. Teori Organisasi : Struktur, Desain, dan Aplikasi. Edisi Terjemahan. Jakarta : Penerbit Arcan.

Schuler, S. Randall dan Jacson, Susan E.. 2010. Manajemen Sumber Daya Manusia Menghadapi Abad ke-21. Jakarta. Erlangga.

Sedarmayanti, 2015. Sumber Daya Manusia dan Produktifitas Kerja. Bandung. CV. Mandar Maju.

Sedarmayanti. 2017.Manajemen Sumber Daya Manusia Revormasi Birokrasi dan Manajemen Pegawai Negeri Sipil, Edisi Revisi, Cetakan kesembilan, Rafika Aditama,PT. Bandung.

Septiadi, Sebastianus Alexander; Sintaasih, Desak Ketut, Wibawa, I Made Artha. 2017. Pengaruh Keterlibatan Kerja Terhadap Kinerja Dengan Pemediasi Komitmen Organisasi. E-Jurnal Ekonomi dan Bisnis Universitas Udayana : 3103-3132

Speitzer, Gretchen M. 1995. Psychological Empowerment In The Workplace : Dimension, Measurement, And Validation. Academy of Management Journal.38 (5): 1442-1465. 
Sugiyono. 1999, “Metode Penelitian Bisnis”, CV Alfabeta, Bandung

Sugiyono. 2017. Statistika Untuk Penelitian. Bandung. Alfabeta Bandung.

Sugiyono. 2018. Metode Penelitian Kuantitatif. Bandung. Alfabeta Bandung.

Sunarta. 2011. Pentingnya Memberdayakan Pegawai Dalam Konteks Perubahan.Tilaar, Ricky; Mekel, ; Peggy Adeline; Tarore, Rita N. 2014. Analisis Komitmen Organisasi, Pengembangan Karir, dan Pemberdayaan Terhadap Kepuasan Kerja Pada Kantor Badan Pengelola Perbatasan Kepulauan Sangihe. Jurnal EMBA Vol. 2 No. 3: 991-1000.

Wibowo. 2008. Manajemen Kinerja. Jakarta. Raja Grafindo Persada. Jakarta.

Wibowo. 2009. Evaluasi Kinerja Sumber Daya Manusia. Jakarta. Salemba Empat Jakarta.

Wibowo. 2016. Manajemen Kinerja . Edisi Kelima. Jakarta. Raja Grafindo Persada. Yani, Ida Maha; Supartha, Wayan Gede; Subudi, Made. 2016. Pengaruh Pemberdayaan dan Kepuasan Kerja Terhadap Komitmen Organisasional Guru di SMK Neg. 1 Mas Ubud. E-Jurnal Ekonomi dan Bisnis Universitas Udayana Vol. 5 No. 12: 4177-4208 
